\title{
Circular economy of ITO thin films deposited on glass obtained from degraded OLED devices
}

\section{Economia circular de filmes finos de ITO depositados sobre vidro obtidos de dispositivos OLEDs degradados}

Emerson Roberto Santos ${ }^{1,2, *}$ (D), Lucas Henrique Silva de Jesus ${ }^{3}$, Elvo Calixto Burini Junior ${ }^{4}$ (D), Roberto Koji Onmori ${ }^{5}$ (D), Wang Shu Hui' (1)

1. Universidade de São Paulo - Escola Politecnica - Engenharia Metalúrgica e de Materiais - São Paulo (SP), Brazil.

2. Laboratório SuperCriativo - São Paulo (SP), Brazil.

3. Faculdade de Tecnologia de São Paulo - Curso de Microeletrônica - São Paulo (SP), Brazil.

4. Universidade de São Paulo - Instituto de Energia e Ambiente - São Paulo (SP), Brazil.

5. Universidade de São Paulo - Escola Politecnica - Engenharia Elétrica - São Paulo (SP), Brazil.

Correspondence author: cientistaemersonsantos@gmail.com

Section Editor: Maria Lúcia Pereira da Silva

Received: 10 Jun 2021 Approved: 20 Jul 2021

\begin{abstract}
In this work, circular economy was investigated for commercial indium tin oxide (ITO) thin films deposited on glass substrates obtained from degraded organic light-emitting diodes (OLED). These devices were assembled and polarized at laboratory in a previous work. For each substrate, with geometry $2.5 \times 2.5 \mathrm{~cm}$, four OLEDs with active area of $3 \times 3 \mathrm{~mm}$ were set up. These OLED devices were assembled with ITO as the electrode anode and successive depositions of other materials (layer-by-layer), to form the complete structure. To obtain the recovered ITO, all layers were removed from the samples containing the OLEDs previously mounted, remaining only the ITO thin films, that were cleaned with commercial product together with the received ITO/glass samples. Both samples were compared using some techniques, such as: colorimetry, electrical resistance, and Raman spectroscopy. A methodology with light-emitting diode (LED) device polarized emitting light crossing the ITO thin films was used, and the luminance with chromaticity coordinates was obtained, revealing the good transparency of the thin films. Electrical resistance of recovered ITO revealed five higher orders of magnitude in comparison to the one of received ITO. This fact can be tributed to a poly(3,4-ethylenedioxythiophene) doped with poly(styrenesulfonate) (PEDOT:PSS) layer, causing corrosion of the ITO thin films during the assembly of OLEDs or loss of the field lines created during the electrical measurements by probes of four-point probe. Raman spectroscopy did not show satisfactory results in the chemical composition analyses of the samples, but it indicated good cleaning process of the samples before the analyses.
\end{abstract}

KEYWORDS: ITO, OLED, Circular economy, Colorimeter, Electrical resistance, Raman spectroscopy.

\begin{abstract}
RESUMO
Neste trabalho, a economia circular foi investigada para filmes finos de óxido de índio e estanho (ITO) comerciais depositados sobre substratos de vidro obtidos de diodos orgânicos emissores de luz (OLEDs) degradados. Esses dispositivos foram montados e polarizados em outro trabalho. Sobre cada lâmina, com geometria de 2,5 × 2,5 cm, foram montados quatro OLEDs com geometria de área ativa de $3 \times 3 \mathrm{~mm}$. Esses dispositivos OLEDs foram montados com eletrodo anodo de ITO e sucessivas deposições de outros materiais (camada por camada), para formar a estrutura completa. Para obter o ITO recuperado, todas as camadas foram removidas de todas as amostras contendo os OLEDs anteriormente montados, restando apenas os filmes finos de ITO, que foram limpos com produto comercial juntamente com outras amostras de ITO/vidro recebidas pelo mesmo fabricante. Ambas as amostras foram comparadas usando algumas técnicas, tais como: colorimetria, resistência elétrica e espectroscopia Raman. Uma metodologia com
\end{abstract}


dispositivo LED polarizado emitindo luz atravessando os filmes finos de ITO foi utilizada, e a luminância com coordenadas de cromaticidade foi obtida, revelando boa transparência dos filmes. Medida de resistência elétrica do ITO recuperado revelou cinco ordens de grandezas maiores em comparação com as do ITO recebido. Esse fato pode ser atribuído pela camada de PEDOT:PSS, causando a corrosão dos filmes finos de ITO durante a montagem dos dispositivos OLEDs ou perda de linhas de campo criadas durante as medidas de resistência elétrica pelas pontas de prova de quatro pontas. Espectroscopia Raman não mostrou resultados satisfatórios nas análises de composição química das amostras, mas revelou bom processo de limpeza das amostras, que foi realizada antes das análises.

PALAVRAS-CHAVE: ITO, OLED, Economia circular, Colorímetro, Resistência elétrica, Espectroscopia Raman.

\section{INTRODUCTION}

Organic light-emitting diodes (OLEDS) can be characterized as electroluminescent semiconductor devices that uses multilayer structures of organic materials ${ }^{1,2}$. The organic multilayer is inserted between an anode used as a transparent conductive oxide (TCO) and a cathode used as a metallic thin film ${ }^{3,4}$. OLED devices were presented in 1987 by two researchers of Eastman Kodak Company known as Ching Wang Tang and Steven Van Slyke5. They announced the creation of an OLED device involving organic materials with multilayer structure such as glass/indium tin oxide (ITO)/diamine/8-tris-hydroxyquinoline aluminum (Alq3)/magnesium (Mg): silver (Ag)

Some years later, the advances of this technology allowed to obtain better efficiency and purity of organic materials with considerable improvement of the performance of OLEDs. Nowadays, these devices are used for some applications, such as: smart televisions, smartphones, smartwatches, luminaires and in automotive area ${ }^{6,7}$. OLEDs have allured the interest of some companies because they have been used as displays substituting the traditional liquid crystal displays (LCDs) with superior advantages, such as: highest brightness, wide view angle $\left(\sim 170^{\circ}\right)$, color reproduction fidelity, high sharpness and low response time $e^{8,9}$. The OLED application in displays with flexible substrates for consumer products has been released by some companies as: Samsung, LG, Motorola and Huawei10-12.

\section{Structure and materials of OLED devices}

In literature, there are multilayer structures for assembling OLED devices with a variable number of thin films, but the structure that has been studied presenting satisfactory results in low voltage and illuminance terms use five layers at least, as showed in Fig. 131,14.

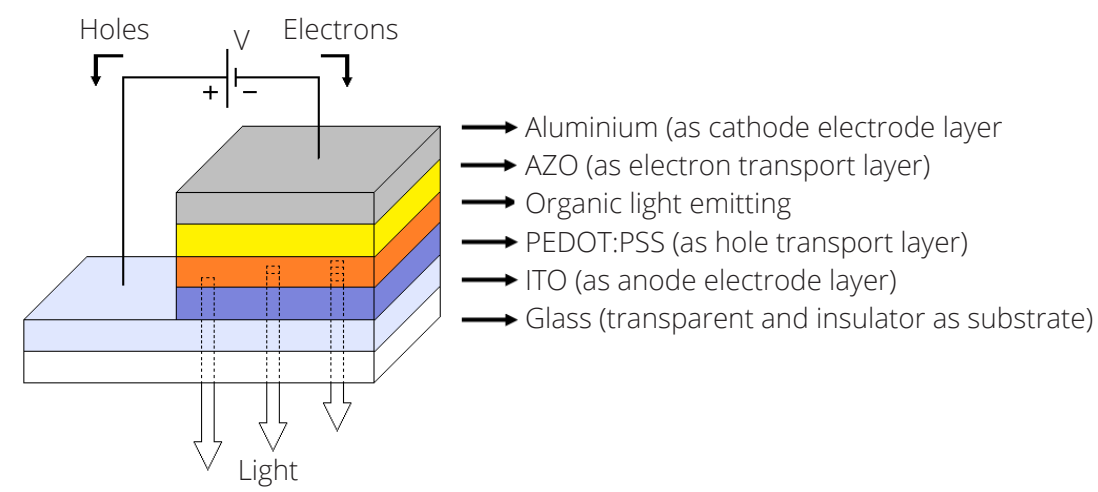

AZO: aluminum-doped zinc oxide nanoparticle ink; PEDOT:PSS: poly(3,4-ethylenedioxythiophene) doped with poly(styrenesulfonate); ITO: indium tin oxide.

Figure 1: Organic light-emitting diode (OLED) devices set up with multilayer involving five thin films.

Rigidness, transparency and electrical insulator are required properties of the glass used as a substrate of OLEDs. Glass also contributes to avoid the diffusion of oxygen and moisture from ambient, both significantly 
leading to degradation of OLED devices ${ }^{15}$. The transparent conductive oxide (TCO) thin film is deposited on the glass substrate. TCO is a type of semiconductor that offers: high optical transparency $(\approx 90 \%)$ to light crossing, good electrical conductivity (from $\approx 7.10^{-5}$ to $5.10^{-4} \Omega . c m$ ), sheet resistance (from 5 to $15 \Omega / \square$ ) and workfunction between 4.5 to $5.3 \mathrm{eV}$. This material is used as an electrode anode, promoting the injection of hole charge carriers inside the OLED ${ }^{16}$.

Successive layers with different functions are deposited on the TCO, such as organic hole transport layer (HTL), to better locomotion of the holes charges; organic active material, to light generation; and organic electron transport layer (ETL), to better locomotion of the electrons charges. On the top of the structure, metal layer is deposited, which is the electrode anode that promotes the electron injection inside the OLED device ${ }^{17}$. To improve the lifetime, threshold voltage and electrical current level are preserved the same, and illuminance is suggested as the encapsulation of the devices ${ }^{18,19}$.

\section{Transparent conductive oxide}

As TCO thin film, ITO has been very used as electrode anode in OLED devices and other ones, such as: organic solar cells (OPVs), LCDs, smart windows, photothermic converters and gas sensors ${ }^{20}$. The ITO thin film has expansive cost, due to indium, that is a rare chemical element found in nature. For this motive, it compromises $\approx 40 \%$ the cost of the OLED devices. ITO thin films are not produced in Brazil, but there are several companies around the world that manufacture them (United States, Japan, England, Hong Kong, South Korea, Taiwan, and China). Table 1 shows the comparison between different manufacturers of ITO thin films deposited on glass as substrates with price, geometry (length $\times$ width $\times$ thickness), sheet resistance and transmittance for 25 substrates (package with minimum number available).

Table 1: Different suppliers of indium tin oxide (ITO) deposited on glass substrates.

\begin{tabular}{cccccc}
\hline \multirow{2}{*}{$\begin{array}{c}* \\
\text { Supplier }\end{array}$} & Code & Sheet resistance & Transmittance & Geometry & Price \\
\cline { 3 - 6 } & & $(\Omega / \square)$ & $(\%)$ & $(\mathbf{m m})$ & $($ US\$) \\
\hline Sigma-Aldrich & 578274-25PAK & $8-12$ & $>83 \%$ & $75 \times 25 \times 1.1$ & 2,253 \\
\hline Diamond Coatings & SL-P-12 OLED & 15 & $\sim 86 \%$ & $355 \times 406 \times 1.1$ & 918 \\
\hline Techinstro & TIX005 & 10 & $>85 \%$ & $100 \times 100 \times 0.7$ & 707 \\
\hline
\end{tabular}

Pure indium (In) oxide without doping of tin $(\mathrm{Sn})$ is considered a material with electrical insulator property, but, when it is modified with oxygen vacancies, there is the possibility to reach high levels of $\mathrm{n}$ type (negative material), due its intrinsic defects ${ }^{21}$. When doped with $\mathrm{Sn}$, this material becomes an impurity donor, because it is a tetravalent element (Sn) doped with a trivalent chemical element (In) ${ }^{22}$. Then, two mechanisms are possible to occur to generate electrical conduction in ITO thin films, such as:

- Carried out by oxygen vacancies in the In oxide structure, donating up to two free electrons to form the $\ln _{2} \mathrm{O}_{3-x}$ structures ${ }^{23,24}$;

- Carried out by random substituting of $\operatorname{In}^{3+}$ ions to $\mathrm{Sn}^{4+}$, donating one electron to the electrical conduction layer25,26.

After these two mechanisms, the ITO increases its carrier concentration, respectively, from $10^{13}$ to $10^{17} \mathrm{~cm}^{-3}$ and from $10^{19}$ to $10^{21} \mathrm{~cm}^{-3} 22,23,27$, a characteristic of semiconductor materials. Although the tin doping improves the electrical characteristic of ITO, there is a limit value that can be used in the material, because there is reduction of Hall mobility, and it considerably causes the decrease of transmittance. Studies report that the best proportion is $10 \mathrm{~mol} \%$ of tin and $90 \mathrm{~mol} \%$ of In oxide ${ }^{22,23}$. Another factor that interferes on the optical and electrical characteristics of ITO is the technique used to fabricate the thin films and also to process the parameters (including the chamber geometry and accessories) used during the deposition. The electrical, optical, and chemical characterization of the ITO thin films can be used:

- Scanning electron microscopy with energy dispersion scattering, to identify the morphology and chemical composition;

- Atomic force microscopy, to verify the surface roughness; 
- Ultraviolet-visible spectrophotometer, to obtain the transmittance or absorbance;

- Hall effect, to investigate the carrier concentration, Hall mobility and electrical resistance;

- Four-point probe, to analyze the sheet resistance;

- Contact angle, to verify the scattering of materials on the surface;

- Ellipsometry, used to identify the doping concentration;

- Profilometer, to obtain the thickness;

- Kelvin probe, ultraviolet photoelectron spectroscopy or x-ray photoelectron spectroscopy, to identify the workfunction of ITO thin films.

\section{The importance of ITO recycling}

Since ITO is present in devices of general applications, it is responsible for high economic, scientific-technological and social impact, because the production of this material influences the quality of human life ${ }^{23}$. Then, the circular economy of this material is fundamental, contributing to the decrease of the production cost of TCOs and also of the waste produced worldwide. Nowadays, the recycling method is responsible for $60 \%$ of the In produced around the world, where the main material is the ITO present in LCDs 25 . Many countries have carried out ITO recycling, such as: China, Japan and South Korea25.

Differently of what happen in these countries, consumer electronic products in Brazil used by people and devices used at research laboratories are sent to landfills, and this attitude has been a significant economic waste. Another problem found in Brazil is related to the expansive cost of ITO/glass, because there is no company to produce this material. Then, to minimize these problems, in this work, the circular economy concept is explored showing a technique to recuperate ITO/glass thin films extracted of degraded OLEDs that were set up and tested at laboratory in a previous work ${ }^{28}$. This material recovered was compared to new substrates (as received) of the same manufacturer/supplier, using optical, electrical, and chemical characterization.

\section{MATERIALS AND METHODS}

The ITO thin films deposited on glass substrates were extracted from degraded OLEDs and studied in another work. The multilayer structure of OLED obtained used the materials: glass/ITO/poly(3,4-ethylenedioxythiophene) doped with poly(styrenesulfonate) (PEDOT:PSS) /poly(N-vinylcarbazole) (PVK)/8-tris-hydroxyquinoline aluminum $\left(\mathrm{Alq}^{3}\right) / \mathrm{Al}^{28}$. Figure 2 shows the materials and geometry of the substrate containing four set-up OLED devices.

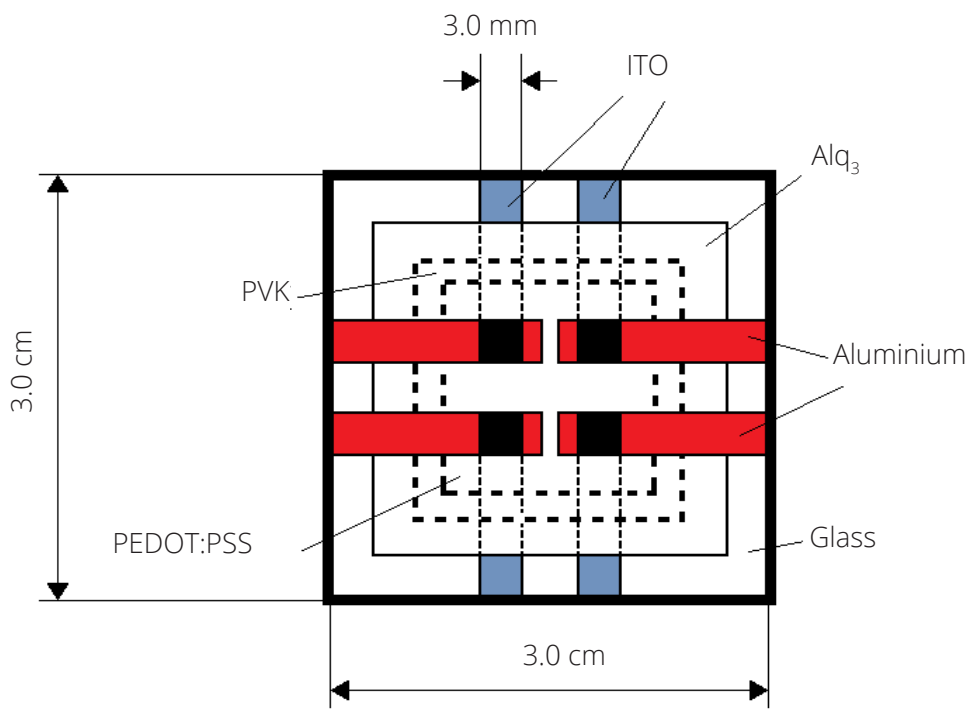

ITO: indium tin oxide; PVK: poly(N-vinylcarbazole); PEDOT:PSS: poly(3,4-ethylenedioxythiophene) doped with poly(styrenesulfonate).

Figure 2: Materials and geometry of the substrates containing four OLED devices ${ }^{28}$. 
On each substrate, four OLED were set up at the same time. Each device presented anode and cathode (only the deposition of organic layers was common for the four devices) inside the glove box system, under nitrogen atmosphere and relative humidity of $20 \%{ }^{29}$. These degraded OLED devices used commercial ITO/glass substrates supplied from DisplayTech company. The samples with ITO/glass recovered were compared to the received samples (new substrates) from the company.

To remove the multilayers of the degraded OLED devices, a five-step process was used:

- Step 1: inside the Becker glass, the samples with degraded OLED were immersed into the alcohol solution, then the Becker was sealed with plastic film (to avoid the evaporation of alcohol) for three days;

- Step 2: cotton and acetone were used for each sample scrubbing to complete remotion of the multilayers (avoiding damaging the ITO thin trails);

- Step 3: inside the Becker, the samples were immersed into acetone, and the Becker was sealed with plastic film (to avoid the evaporation of acetone) for eight days to remove possible residues;

- Step 4: inside the Becker, the samples were immersed into the current water for six days;

- Step 5: to remove any remnants cotton scrubbing with a domestic abrasive cleaning product was used on the surface of the substrates, including the ITO trails.

This cleaning method was suggested and selected for this investigation, because it causes no changes (decrease of the thickness, for example) in the property of the ITO thin films.

After recuperation of ITO thin films, all samples (including the received ones) were cleaned by a process to remove possible particles, dust, and grease, using rubber gloves, common detergent and current water scrubbing the surfaces. Then, a product commercialized in Brazilian market called Aqua Brilho Restaurador de Superfície was used, putting some drops and scrubbing with cotton until the complete evaporation of the solvent (water), finishing the cleaning method ${ }^{30}$.

\section{Characterization of commercial ITO/glass}

Optical characteristics of ITO thin films were analyzed using a chroma meter manufactured by Konica Minolta, model CS-200, to obtain luminance $\left(\mathrm{cd} / \mathrm{m}^{2}\right)$ and chromaticity coordinates $(x$ and $\mathrm{y})$. In this technique, a LED with white emission was polarized at $2.50 \mathrm{~V}$ and $0.032 \mathrm{~mA}$ using a source power manufactured by Keithley, 2400 series. In this analysis methodology, the ITO trail was placed between LED and chroma meter with 15-cm of distance. Figure 3 shows the arrangement of the experiment used. The analyses were carried out at a laboratory with a turned-off ambient illumination (to avoid possible interferences in the measurements). The LED was measured (without interference of the ITO thin film) as reference. To the ITO recovered, four measurements were obtained, and to the received ones three measurements were obtained.

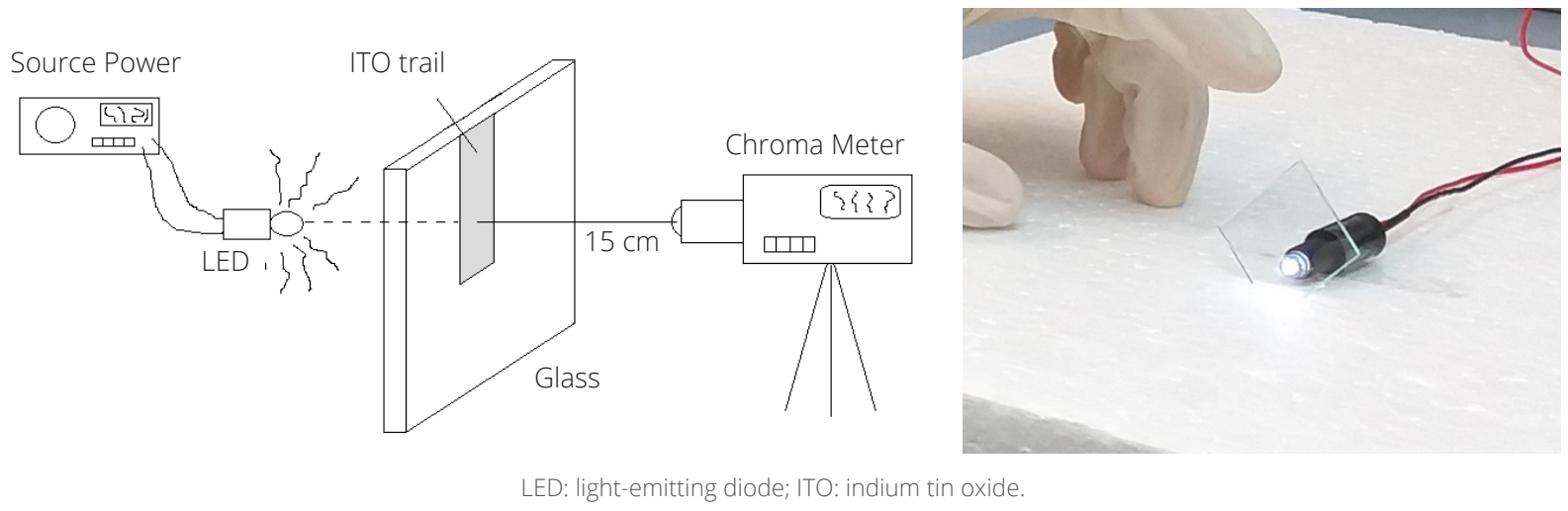

Figure 3: Arrangement using chroma meter, LED and ITO thin film.

Electrical characteristic of ITO thin films was analyzed using a digital multimeter manufactured by Tektronix, model DMM 4020, connected to an analogic four-point probe manufactured by A\&M Fell, model B. The probe cords (positive and negative) of digital multimeter were connected to the electrical connectors of four-point 
probe, and the sample was positioned on the center of the horizontal support of the equipment. Measurements were manually initialized moving the crowbar to turn down containing the two probes up to touch the surface of ITO thin film.

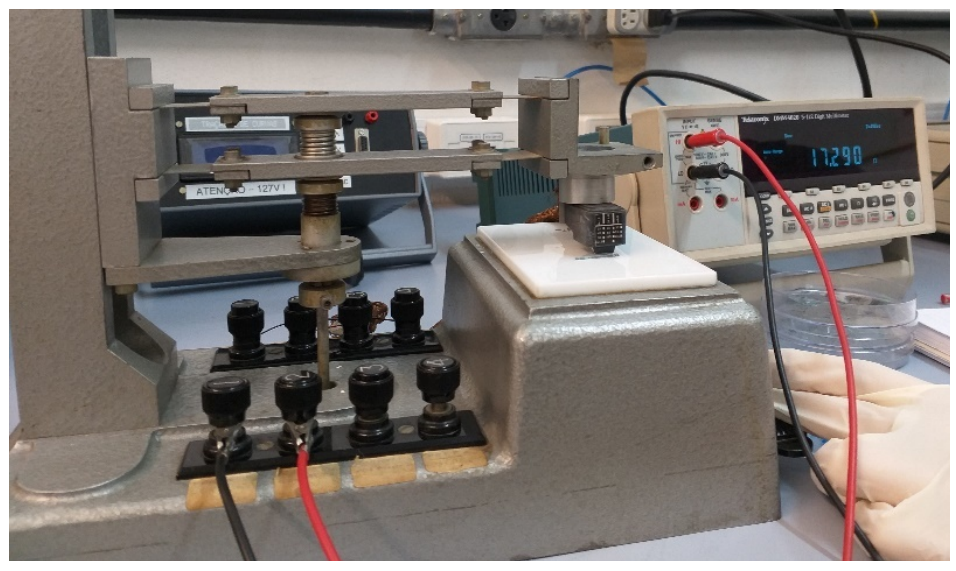

Figure 4: Analogic four-point probe connected by multimeter to analyze electrical resistance.

Chemical characteristic of ITO thin films was analyzed by Raman spectroscopy to investigate the chemical composes on the surface. The equipment used was manufactured by Witec, Confocal Raman microscope, model Alpha 300 R, that uses green laser and objective lens with magnification level of 50x. In this technique, inelastic monochromatic light spreads on the molecules.

\section{RESULTS}

\section{Analyses with chroma meter}

\section{Analyses of LED}

Five analyses with chroma meter revealed good precision on luminance, and the chromaticity coordinates ( $x$ and y) results showed good stability of the light emission for the experiments using LED. Luminance measurements revealed little variation that only can be caused by oscillations of the energy line (power supply connected to 110 volts) or frequency used with power line of $60 \mathrm{~Hz}$ (turned-on and turned-off). For this motive, both electrical characteristics might have affected the sensibility of chroma meter. Table 2 shows the luminance and chromaticity coordinates ( $x$ and $y$ ) of LED with white emission polarized at $2.5 \mathrm{~V}$ and $0.032 \mathrm{~mA}$.

Table 2: Luminance and chromaticity coordinates results to the light-emitting diode (LED) polarized at $2.5 \mathrm{~V}$ and $0.032 \mathrm{~mA}$.

\begin{tabular}{|c|c|c|c|}
\hline \multirow{2}{*}{ LED } & \multirow{2}{*}{$\begin{array}{l}\text { Luminance } \\
\qquad\left(\mathrm{cd} / \mathrm{m}^{2}\right)\end{array}$} & \multicolumn{2}{|c|}{ Chromaticity coordinates } \\
\hline & & $\mathrm{x}$ & y \\
\hline \multirow{5}{*}{ Polarized at $2.50 \mathrm{~V}$ e $0.032 \mathrm{~mA}$} & 2,677 & 0.2658 & 0.2663 \\
\hline & 2,678 & 0.2658 & 0.2663 \\
\hline & 2,679 & 0.2658 & 0.2663 \\
\hline & 2,680 & 0.2658 & 0.2663 \\
\hline & 2,679 & 0.2658 & 0.2664 \\
\hline Average \pm standard deviation & $2,679 \pm 1$ & $0.2658 \pm 0.0000$ & $0.2663 \pm 0.0000$ \\
\hline
\end{tabular}




\section{Analyses of ITO/glass thin films}

Both received and recovered ITO/glass substrates were placed in front of the polarized LED at the same conditions using only the LED. Five analyses with chroma meter revealed good precision on results obtained by luminance and chromaticity coordinates $x$ and $y$ (with four decimal numbers), and good stability of the light emission for only LED. For received ITO/glass, the illuminance and chromaticity coordinates measurements were carried out at three different regions ( $a, b$ and $c)$ on the same received sample.

The values in Table 3 reveal good uniformity of thin films with luminance value of $2,484 \pm 15 \mathrm{~cd} / \mathrm{m}^{2}$ and low standard deviation for the same received sample.

Table 3: Received sample: luminance and chromaticity coordinates for indium tin oxide (ITO) as received/glass/light-emitting diode (LED) measured at different regions ( $a, b$ and $c$ ).

\begin{tabular}{|c|c|c|c|}
\hline \multirow{2}{*}{ Region } & \multirow{2}{*}{$\begin{array}{l}\text { Luminance } \\
\qquad\left(\mathrm{cd} / \mathrm{m}^{2}\right)\end{array}$} & \multicolumn{2}{|c|}{ Chromaticity coordinates } \\
\hline & & $x$ & $y$ \\
\hline & 2,500 & 0.2667 & 0.2746 \\
\hline & 2,500 & 0.2667 & 0.2746 \\
\hline \multirow[t]{3}{*}{ a } & 2,501 & 0.2666 & 0.2745 \\
\hline & 2,502 & 0.2666 & 0.2746 \\
\hline & 2,500 & 0.2667 & 0.2745 \\
\hline \multirow[t]{3}{*}{$\begin{array}{l}\text { Average } \pm \text { standard } \\
\text { deviation }\end{array}$} & $2,501 \pm 1$ & $0.2666 \pm 0.0001$ & $0.2746 \pm 0.0001$ \\
\hline & 2,467 & 0.2648 & 0.2707 \\
\hline & 2,465 & 0.2648 & 0.2706 \\
\hline \multirow[t]{3}{*}{$b$} & 2,467 & 0.2648 & 0.2707 \\
\hline & 2,467 & 0.2648 & 0.2707 \\
\hline & 2,466 & 0.2648 & 0.2707 \\
\hline \multirow[t]{3}{*}{$\begin{array}{l}\text { Average } \pm \text { standard } \\
\text { deviation }\end{array}$} & $2,467 \pm 1$ & $0.2648 \pm 0.0000$ & $0.2707 \pm 0.0001$ \\
\hline & 2,485 & 0.2676 & 0.2759 \\
\hline & 2,482 & 0.2676 & 0.2759 \\
\hline \multirow[t]{3}{*}{ c } & 2,485 & 0.2675 & 0.2759 \\
\hline & 2,486 & 0.2675 & 0.2759 \\
\hline & 2,485 & 0.2675 & 0.2759 \\
\hline $\begin{array}{l}\text { Average } \pm \text { standard } \\
\text { deviation }\end{array}$ & $2,485 \pm 2$ & $0.2675 \pm 0.0001$ & $0.2759 \pm 0.0000$ \\
\hline
\end{tabular}

The luminance and chromaticity coordinates ( $x$ and $y$ ) measurements for ITO/glass recovered were obtained at the same regions of active areas $(4 \times 4 \mathrm{~mm}$ ) from OLEDs (with four devices obtained at the same substrate) previously assembled and tested. These regions were named as R1, R2, R3 and R4. In comparison of received and recovered ITO/glass, insignificant differences were verified, suggesting that the recovered ITO/glass had some changes in its optical characteristic (transmittance, for example) caused by multilayers structure of OLED. 
Table 4: Recovered sample: luminance and chromaticity coordinates for indium tin oxide (ITO) recovered/glass/light-emitting diode (LED) measured at different regions (R1, R2, R3 and R4).

\begin{tabular}{|c|c|c|c|}
\hline \multirow{2}{*}{ Region } & \multirow{2}{*}{$\begin{array}{l}\text { Luminance } \\
\qquad\left(\mathrm{cd} / \mathrm{m}^{2}\right)\end{array}$} & \multicolumn{2}{|c|}{ Chromaticity coordinates } \\
\hline & & $\mathrm{x}$ & $y$ \\
\hline & 2,466 & 0.2639 & 0.2686 \\
\hline & 2,467 & 0.2640 & 0.2686 \\
\hline \multirow[t]{3}{*}{ R1 } & 2,468 & 0.2640 & 0.2686 \\
\hline & 2,469 & 0.2639 & 0.2686 \\
\hline & 2,471 & 0.2640 & 0.2686 \\
\hline \multirow[t]{3}{*}{$\begin{array}{l}\text { Average } \pm \text { standard } \\
\text { deviation }\end{array}$} & $2,468 \pm 2$ & $0.2640 \pm 0.0001$ & $0.2686 \pm 0.0000$ \\
\hline & 2,471 & 0.2644 & 0.2684 \\
\hline & 2,473 & 0.2644 & 0.2684 \\
\hline \multirow[t]{3}{*}{ R2 } & 2,475 & 0.2644 & 0.2684 \\
\hline & 2,478 & 0.2644 & 0.2685 \\
\hline & 2,478 & 0.2644 & 0.2684 \\
\hline \multirow[t]{3}{*}{$\begin{array}{l}\text { Average } \pm \text { standard } \\
\text { deviation }\end{array}$} & $2,475 \pm 3$ & $0.2644 \pm 0.0000$ & $0.2684 \pm 0.0001$ \\
\hline & 2,461 & 0.2657 & 0.2706 \\
\hline & 2,463 & 0.2657 & 0.2706 \\
\hline \multirow[t]{3}{*}{ R3 } & 2,464 & 0.2656 & 0.2705 \\
\hline & 2,465 & 0.2656 & 0.2704 \\
\hline & 2,466 & 0.2656 & 0.2704 \\
\hline \multirow[t]{3}{*}{$\begin{array}{c}\text { Average } \pm \text { standard } \\
\text { deviation }\end{array}$} & $2,464 \pm 2$ & $0.2656 \pm 0.0001$ & $0.2705 \pm 0.0001$ \\
\hline & 2,492 & 0.2653 & 0.2704 \\
\hline & 2,490 & 0.2653 & 0.2704 \\
\hline \multirow[t]{3}{*}{ R4 } & 2,488 & 0.2652 & 0.2703 \\
\hline & 2,488 & 0.2652 & 0.2703 \\
\hline & 2,487 & 0.2652 & 0.2703 \\
\hline $\begin{array}{c}\text { Average } \pm \text { standard } \\
\text { deviation }\end{array}$ & $2,489 \pm 2$ & $0.2652 \pm 0.0001$ & $0.2703 \pm 0.0001$ \\
\hline
\end{tabular}

\section{Analyses of Raman spectroscopy}

The chemical analyses to common glass, received ITO and recovered ITO were carried out by Raman spectroscopy. As reference measurement, first, the analysis of previous-cleaned common glass manufactured by Precision Glass Line company was obtained. Figure 5 shows the results of Raman spectroscopy to the common 
glass with wavenumber of $\approx 1,100 \mathrm{~cm}^{-1}$, that is related by relative peak of the asymmetric chemical bond Si-O-Si. The wavenumber from 2,850 to 2,900 $\mathrm{cm}^{-1}$ is related to the chemical bond of carbon with hydrogen.

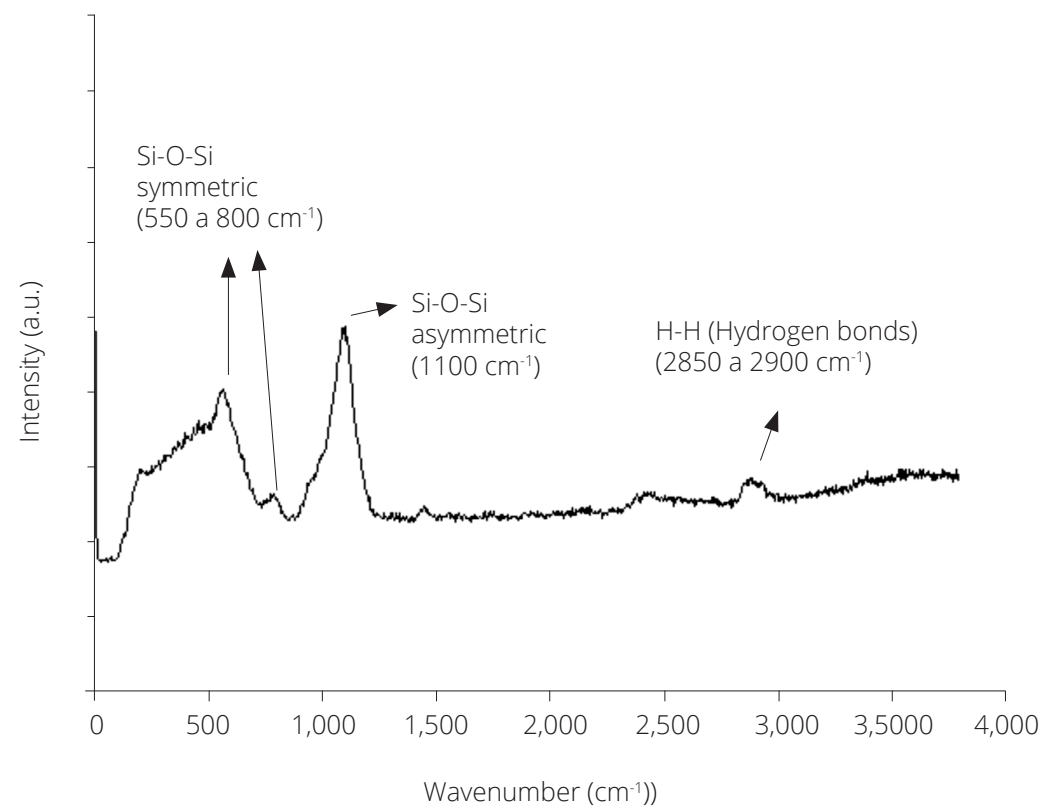

Figure 5: Raman spectroscopy of common glass substrate (without indium tin oxide thin film) used as reference.

In Fig. 6, received ITO thin film shows similar aspects compared with glass (Fig. 5), but it was found a peak shift of $\mathrm{C}-\mathrm{H}$ from 2,850 to $2,900 \mathrm{~cm}^{-1}$ to the lowest wavelength, from 2,380 to $2,500 \mathrm{~cm}^{-1}$.

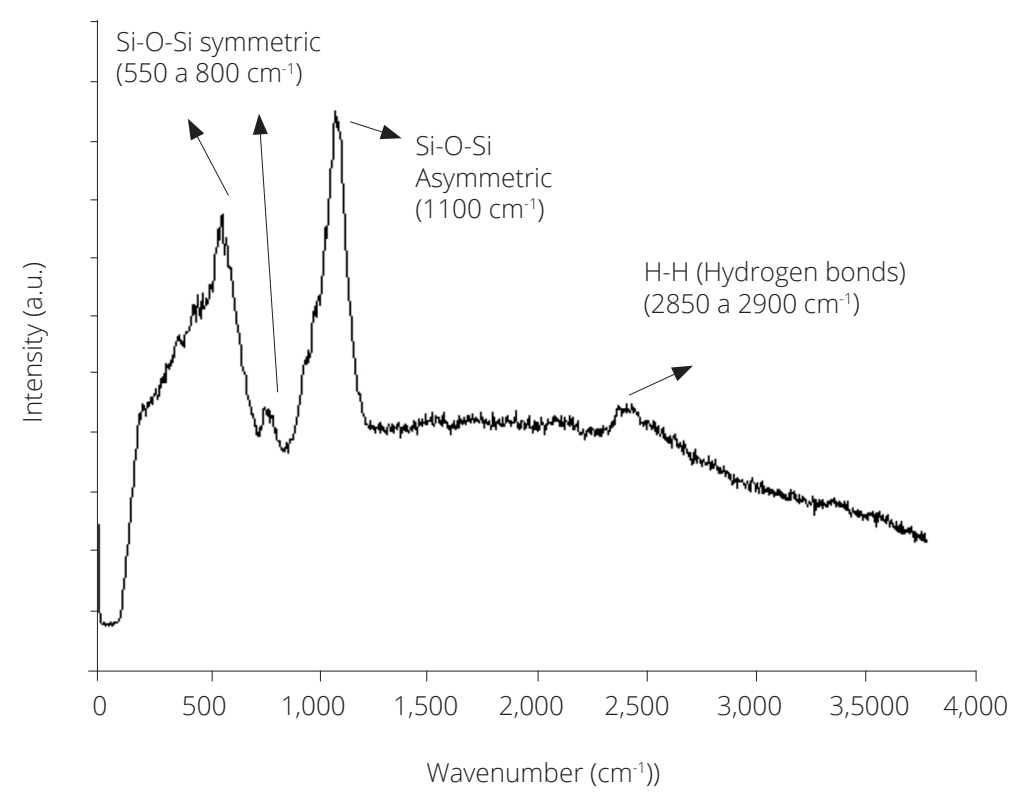

Figure 6: Raman spectroscopy of indium tin oxide (ITO)/received glass.

In comparison between ITO/received glass (Fig. 6) and ITO/recovered glass (Fig. 7), a similar behavior was verified, and new compounds adsorbed on the surface were not found. 


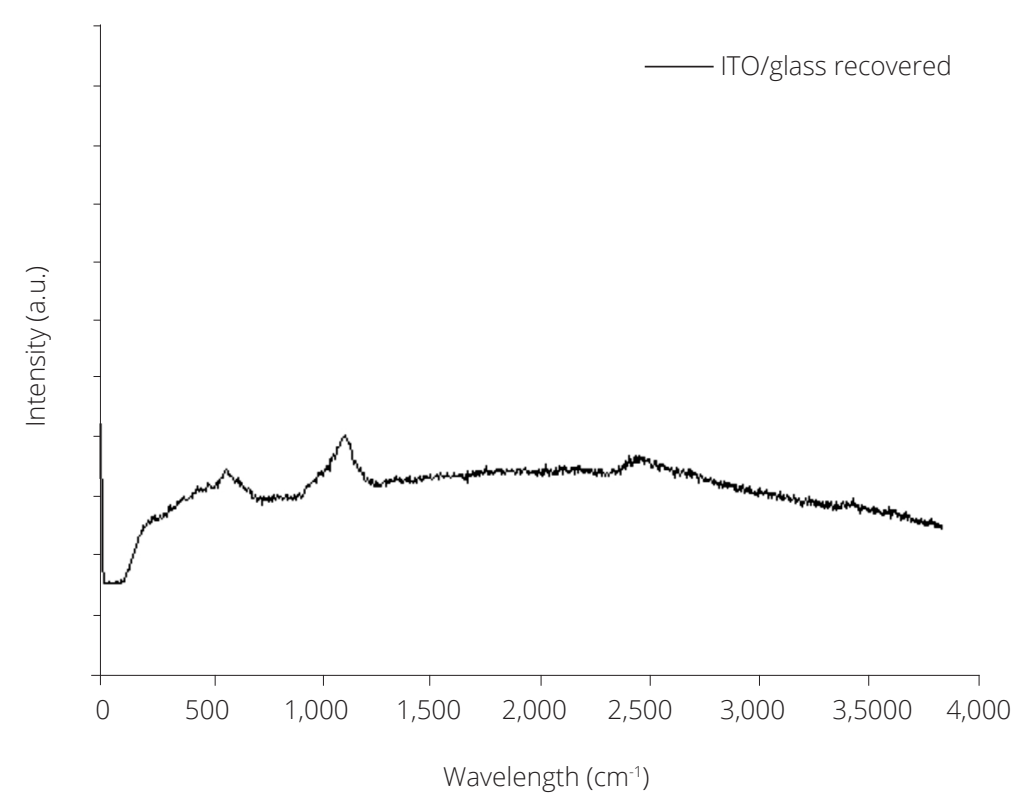

Figure 7: Raman spectroscopy of indium tin oxide (ITO)/recovered glass.

\section{Analyses of electrical resistance with four-point probe}

Table 5 presents the results of electrical resistance to ITO/received glass and ITO/recovered glass, showing a significant difference as high electrical resistance involving five orders of magnitude between both conditions.

Table 5: Electrical resistance measurements of indium tin oxide (ITO)/received glass and ITO/recovered glass.

\begin{tabular}{cc}
\hline $\begin{array}{c}\text { ITO/received glass } \\
(\Omega .10)\end{array}$ & $\begin{array}{c}\text { ITO/recovered glass } \\
\left(\Omega .10^{5}\right)\end{array}$ \\
\hline 82 & 3.40 \\
\hline 55 & 3 \\
\hline 74 & 5.80 \\
\hline 76 & 4 \\
\hline 94 & 5.40 \\
\hline & Average \pm standard deviation \\
\hline $75 \pm 14$ & $4.18 \pm 1.23$ \\
\hline
\end{tabular}

The hypothesis for this discrepant result found in Table 5 can be explained because of ITO/recovered glass was corroded by PEDOT:PSS layer, that is the first material deposited during the assembly of OLED devices. In this case, this HTL presented acidity ( $\mathrm{pH}$ of $1.5-2.5$ and $25^{\circ} \mathrm{C}$ to dried coatings), causing chemical attack on the surface of ITO thin films. In turn, the original thickness of ITO (656 nm) decreased, and consequently the electrical resistance and sheet resistance increased considerably28,31,32. If this ITO manufactured by DisplayTech company decreased in thickness for some reason, it can be still used as an anode electrode for assembly new OLED devices, since its original thickness is very elevated in comparison to other suppliers, as reported in Fullenbach ${ }^{28}$. For example, Fullenbach ${ }^{28}$ found a thickness variation from 16 to $83 \%$ related to different suppliers. 
Figure 8 shows the chemical attack (spots) caused by three PEDOT:PSS droplets placed on the surface of ITO thin films that were left by some days and removed causing visual changes on the original color of TCO. There is a possibility that these significant changes cause variations of the thickness.

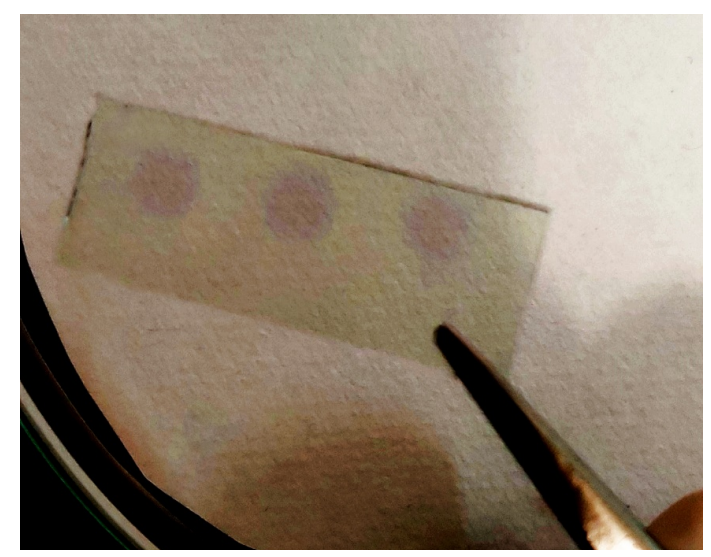

Figure 8: Three spots caused by acidity of poly(3,4-ethylenedioxythiophene) (PEDOT:PSS ) on indium tin oxide (ITO) thin film.

Another hypothesis related to the difference of the electrical resistance values for both ITOs can be related to the thin trails of ITO/recovered glass used as electrical pads. In this case, during the electrical resistance measurements by four-point probe, discontinuity of the electrical field lines may have occurred, promoted by probes, and consequently increases of the electrical resistance. This condition of measurements used to thin trails of the recovered ITO films presented limitation of the method proposed. For this motive, the result obtained was not very conclusive. This fact did not occur with ITO/received glass, because the superficial area of ITO was much higher than the distance between the two probes used, presenting less than $1 \mathrm{~mm}$.

\section{CONCLUSION}

Commercial ITO thin films deposited on glass substrates were obtained from degraded OLED devices and compared with received ones from suppliers. Both materials were investigated through optical, chemical, and electrical characterizations. The recovered ITO/glass thin films presented insignificant variations on the optical results, as luminance and chromaticity coordinates, when it was compared with received samples.

The electrical analyses of recovered ITO/glass showed high electrical resistances, that can be related to thin trails (used during the OLEDs set up). Because of that, there was loss in electrical field lines of probes used during the analyses. Another motive for the found high electrical resistance values can be related to partial corrosion of the thin film caused by ITO chemical attack, due to the acidity of PEDOT:PSS layer, that is the first material deposited on ITO during the OLED devices assemblance. In turn, thickness measurements of recovered ITO are suggested.

The analyses of Raman spectroscopy did not show significant results, but it revealed that the cleaning method of samples may have been effective, because the result pointed out no new chemical compounds adsorbed on the surface. To prove that circular economy technique is efficient to the recuperation of ITO thin films, it is suggested the assembly of new OLED devices using the same previous structure of multilayers. This method guarantees that no new variable is included during the assembly process.

The circular economy in OLED devices may be a promising technique for the future of technology, mainly in Brazil, because there is no TCO company in the country. The price of TCOs in the Brazilian market is very expansive and it represents a very expressive cost in OLED devices.

\section{ACKNOWLEDGMENTS}

The authors thank the Escola Politécnica of Universidade de São Paulo, Engenharia Metalúrgica e de Materiais, for providing facilities and equipments. 


\section{AUTHOR'S CONTRIBUTION}

Conceptualization, Data curation, Formal analysis, Funding acquisition, Methodology, Resources, Supervision, Validation, Visualization, Writing - original draft, Writing - review \& editing: Santos ER; Conceptualization, Data curation, Formal analysis, Methodology, Visualization, Writing - original draft: Jesus LHS; Conceptualization: Burini Junior; Conceptualization, Funding acquisition, Methodology, Resources, Software: Hui WS; Funding acquisition: Onmori RK; Conceptualization: Hui WS.

\section{FUNDING}

Coordenação de Aperfeiçoamento de Pessoal de Nível Superior (CAPES)

[http://doi.org/10.13039/501100002322]

(PNPD Project No 02998/09-2).

\section{DATA AVAILABILITY STATEMENT}

Data are available in a data repository.

Jesus L HS. Economia Circular em Dispositivos OLEDs [undergraduate thesis]. São Paulo: Faculdade de Tecnologia de São Paulo; 2020.

\section{REFERENCES}

1. Zade G. Development of blue emitting organic phosphors of diphenylquionial (DPQ) group for OLED. Int J Adv Res Sci Commun Technol. 2021;3(2):44-6. https://doi.org/10.48175/IJARSCT-854

2. Zhang Z, Xia L, Liu L, Chen W, Wang Z, Wang W, et al. Ultra-smooth and robust graphene-based hybrid anode for high-performance flexible organic light-emitting diodes. J Mater Chem C. 2021;9(6):2106-14. https://doi. org/10.1039/d0tc05213b

3. Xu T, Liang X, Xie G. Solution-processed pure blue thermally activated delayed fluorescence emitter organic lightemitting diodes with narrowband emission. Front Chem. 2021;9:1-5. http://doi.org/10.3389/fchem.2021.691172

4. Su S-H, Huang C-Y, Lin Y-S. White field-emission organic light-emitting diodes using aco-dopant emitter. Int J Eng Res Appl. 2021;11(1):8-11. http://doi.org/10.9790/9622-1101010811

5. Tang CW, VanSlyke SA. Organic electroluminescent diodes. Appl Phys Lett. 1987;51(12):913-5. http://doi. org/10.1063/1.98799

6. Universal Display Corporation. OLED investor presentation [Internet]. UDC; 2021 [cited on Jun 2021]. Available from: https://static.seekingalpha.com/uploads/sa_presentations/932/70932/original.pdf

7. Splinder J. OLED manufacturing challenges. OLED Works. DOE Lighting R\&D Workshop [Internet]. UDC; 2021 [cited on Jun 2021]. Available from: https://www.energy.gov/sites/prod/files/2021/02/f82/ssl-rd21-spindlerchallenges.pdf

8. Freundenrich C. How OLEDs work. OLED advantages and disadvantages [Internet]. 2021 [cited on Jun 2021]. Available from: https://electronics.howstuffworks.com/oled5.htm

9. Polymer Science Incorporation. Our innovation. Your edge. OLED. Catalogue [Internet]. 2017 [cited on Jun 2021]. Available from: https://polymerscience.com/wp-content/uploads/2018/05/OLED-Brochure.pdf

10. LG. The great moments in Las Vegas: LG Signature delivers memorable showcase at CES 2021 [Internet]. 2021 [cited on Jun 2021]. Available from: https://www.lg.com/global//g-signature/brand/art-culture/ces-2021 
11. Schneemann G. Samsung's Galaxy Z Fold 2 improves on many fronts. OMDIA [Internet]. 2020 [cited on Jun 2021]. Available from: https://omdia.tech.informa.com/-/media/tech/omdia/assetfamily/2020/09/01/samsungsgalaxy-z-fold-2-improves-on-many-fronts/exported/samsungs-galaxy-z-fold-2-improves-on-many-fronts-pdf. pdf?sc_lang=en

12. My Mobile. Your gateway to the world of mobility. Foldable smartphones! Sensible or Senseless? [Internet]. 2019 [cited on Jun 2021]. Available from: https://www.mymobileindia.com/wp-content/uploads/2019/04/All-Low-ResMarch-19-1.pdf

13. Sharma A, Das TD. Light extraction efficiency analysis of phosphorescent OLED device with microlens array on the glass substrate. Opt Quant Electron. 2021;1-16. https://doi.org/10.21203/rs.3.rs-482200/v1

14. Karunathilaka BSB, Balijapalli U, Senevirathne CAM, Yoshida S, Esaki Y, Goushi K, et al. Suppression of external quantum efficiency rolloff in organic light emitting diodes by scavenging triplet excitons. Nat Commun. 2020;11:4926. https://doi.org/10.1038/s41467-020-18292-0

15. Sisk S, Koh J, Su, Bowden B. Corning LotusTM NXT Glass, through its advantaged and balanced glass attributes, was designed to address the challenges of today's LTPS-OLED manufacturing processes [Internet]. Corning Incorporated; 2021 [cited on Jun 2021]. Available from: https://www.corning.com/media/worldwide/cdt/ documents/Lotus_NXT_Glass_for_OLED_White_Paper.pdf

16. Pozov SM, loakeimidis A, Papadas IT, Sun C, Chrusou AZ, Bradley DDC, et al. Bottom contact metal oxide interface modification improving the efficiency of organic light emitting diodes. Materials. 2020;13:1-12. http:// doi.org/10.3390/ma13225082

17. Kang SW, Baek D-H, Ju B-K, Park YW. Green phosphorescent organic light-emitting diode exhibiting highest external quantum efficiency with ultra-thin undoped emission layer. Sci Rep. 2021;11:8436. https://doi. org/10.1038/s41598-021-86333-9

18. Wu J, Fei F, Wei C, Chen X, Nie S, Zhang D, et al. Efficient multi-barrier thin film encapsulation of OLED using alternating Al2O3 and polymer layers. RSC Adv. 2018;8(11):5721-7. https://doi.org/10.1039/c8ra00023a

19. Sandrez S, Della-Gatta SM, Maindron T. Impact of pixel surface topography onto thin-film encapsulated top-emitting organic light-emitting diodes performances. Thin Solid Films. 2020;699:137869. https://doi. org/10.1016/j.tsf.2020.137869

20. Ellmer K. Past achievements and future challenges in the development of optically transparent electrodes. Nat Photonics. 2012;6:809-17. https://doi.org/10.1038/nphoton.2012.282

21. Jimenez LC, Méndez HA, Páez BA, Ramírez ME, Rodríguez J. Production and characterization of indium oxide and indium nitride. Braz J Phys. 2006;36(3B):1017-20. https://doi.org/10.1590/S0103-97332006000600058

22. Damiani LR. Filmes de óxido de índio dopado com estanho depositado por magnetron sputtering [Master Science dissertation]. São Paulo: Escola Politécnica de Engenharia Elétrica da Universidade de São Paulo; 2010.

23. Oliveira FMB. Método solvotérmico assistido por micro-ondas aplicado à obtenção de nanocristais de ITO: deposição e caracterização de filmes de ITO [Master Science dissertation]. São Carlos: Ciências Exatas e da Terra da Universidade Federal de São Carlos; 2012.

24. Tahar RBH, Ban T, Ohya Y, Takahashi Y. Tin doped indium oxide thin films: Electrical properties. J Appl Phys. 1998;83(5):2631-45. https://doi.org/10.1063/1.367025

25. Monteiro APM, Sousa ABM, Rossetti AKS, Maia DLS, Martins CHZ, Alves OL. Índio: uma visão científica e tecnológica de um metal estratégico. Quím Nova. 2019;42(10):1162-71. http://doi.org/10.21577/0100-4042.20170446

26. Franz G, Lange B, Sotier S. Characterization of sputtered indium tin oxide layers as transparent contact material. J Vac Sci Technol. 2001;19:2514-21. https://doi.org/10.1116/1.1389901

27. Santos ER. Estudos de tratamentos superficiais em substratos de óxidos transparentes condutivos para a fabricação de dispositivos poliméricos eletroluminescentes. São Paulo: Escola Politécnica de Engenharia Elétrica da Universidade de São Paulo; 2009. 
28. Fullenbach TC. Estudo de diferentes TCOs utilizados como eletrodos anodos em dispositivos OLEDs [undergraduate thesis]. São Paulo: Faculdade de Tecnologia de São Paulo; 2019.

29. Santos ER, Fullenbach TC, Medeiros MS, Zambom LS, Onmori RK, Hui WS. Different electrode anodes used in OLED devices. Rev Bras Aplic Vácuo. 2021;40(1):1-17. https://doi.org/10.17563/rbav.v40.1205

30. Santos ER, Ono ETY, Yoshida S, Oide MYT, Burini Junior EC, Onmori RK, et al. Thin films of zinc oxide doped with aluminium (AZO) used in OLED device structures. Rev Bras Aplic Vácuo. 2018;37(3):139-44. https://doi. org/10.17563/rbav.v37i2.1081

31. Nardes AM. On the conductivity of PEDOT:PSS thin films [PhD doctor thesis online]. Eindhoven: Technische Universiteit Eindhoven; 2007 [cited on Aug 16, 2021]. Available from: https://www.teses.usp.br/teses/ disponiveis/3/3140/tde-27032015-150109/publico/Tese_AlexandreMNardes_SemFC_SemResumo.pdf

32. Merck. Sigma-Aldrich. properties of poly(3,4-ethylenedioxythiophene)-poly(styrenesulfonate). 2021 [cited on Jun. 2021]. Available from: https://www.sigmaaldrich.com/BR/en/product/aldrich/655201 